\title{
Adherence of non-enteropathogenic Escherichia coli to HeLa cells
}

\author{
S. BOUZARI, A. JAFARI, A. A. FARHOUDI-MOGHADDAM, F. SHOKOUHI and M. PARSI
}

Molecular Biology Unit, Pasteur Institute, Pasteur Avenue, Tehran 13164, Iran

\begin{abstract}
Summary. Three hundred and nine strains of Escherichia coli isolated from infants and children with diarrhoea but not belonging to any recognised classes of diarrhoeagenic $E$. coli were investigated for their ability to adhere to HeLa cells in the presence of D-mannose. An enteroadherent-aggregative pattern (EAgg) was observed in $32.03 \%$, localised adherence (LA) in $4.5 \%$, diffuse adherence (DA) in $5.8 \%$, and LA/DA and EAgg/LA in $1.9 \%$ and $1.2 \%$ of the isolates respectively. The results obtained with 100 control isolates were: EAgg $17 \%$, LA $2 \%$, DA $2 \%$, LA/DA $2 \%$, EAgg/LA $6 \%$ and DA/EAgg $1 \%$. No adherence was manifested by $168(54.36 \%)$ of 309 diarrhoeal isolates and $70 \%$ of the 100 control isolates. The results of this study showed that amongst non-enteropathogenic $E$. coli, strains exhibiting the EAgg pattern are significantly associated with diarrhoea $(\mathrm{p}<0.005)$. Most of these strains showed a pattern of multiple drug resistance.
\end{abstract}

\section{Introduction}

Bacterial adherence to the intestinal mucosa has been identified as characteristic of Escherichia coli strains that cause diarrhoea in infants. ${ }^{1}$ The observation that most enteropathogenic $E$. coli adhered to HEp-2 cells in vitro whereas non-pathogenic strains rarely did so led to the use of tissue-culture adherence assays to identify diarrhoeagenic $E$. coli strains. ${ }^{2}$ Three patterns of adherence have been described: localised adherence (LA) in which microcolonies are formed at one or more places on the cells (HeLa or HEp-2), diffuse adherence (DA) where bacteria cover the cells uniformly ${ }^{3}$ and the enteroadherent-aggregative pattern (EAgg) in which the bacteria have a characteristic stacked brick appearance on the surface of the cells and on the glass slide free from the cells. ${ }^{4}$ Studies conducted so far have suggested that $E$. coli with an LA pattern and belonging to enteropathogenic serotypes (EPEC) are associated with diarrhoea., ${ }^{5,6}$ The role of $E$. coli showing a DA pattern is controversial $1^{5,7}$ and strains showing an EAgg pattern (EAggEC) have been incriminated as causing diarrhoea in children on the basis of epidemiological studies. ${ }^{8,9}$ The present study was undertaken to determine the importance of adherent non-EPEC and EAggEC strains among $E$. coli isolates from diarrhoeal stools.

\section{Materials and methods}

\section{Bacterial strains}

Three hundred and nine biochemically confirmed $E$. coli strains isolated from infants and children with diarrhoea from whom no other bacterial pathogen had been isolated were studied and 100 strains from nondiarrhoeal age-matched infants and children attending the same hospital for vaccination purposes were used as controls. These strains were non-EPEC by slide agglutination with poly- and monovalent $\mathrm{O}$ antisera (Diagnostics Pasteur, France). They were nontoxigenic in the infant mouse assay for heat-stable enterotoxin and the reversed passive latex agglutination test for heat-labile enterotoxin (Denka Seiken Co. Ltd, Japan). They failed to bind Congo red (Janssen Chimica, Belgium) and did not cause keratoconjunctivitis. These strains were also tested for their ability to ferment sorbitol with Sorbitol-MacConkey Agar (Difco).

\section{Adherence assay}

Strains were tested for adherence to $\mathrm{HeLa}$ cells in the presence of D-mannose (Merck, Germany) $1 \%$ by the procedure of Scaletsky et al. ${ }^{3}$ An overnight culture $(50 \mu \mathrm{l})$ grown in Trypticase Soya Broth (Difco) was added to HeLa cell monolayers grown on coverslips in Leighton tubes. The inoculated cells were incubated at $37^{\circ} \mathrm{C}$ for $30 \mathrm{~min}$ (infection period), washed twice and incubated for a further $3 \mathrm{~h}$ (multiplication period). The cells were then washed twice, fixed in methanol:acetic acid $(3: 1)$, stained with Giemsa (Merck, Germany) and observed by light microscopy. The patterns of adherence were assessed according to Scaletsky et al. ${ }^{3}$ for LA and DA and Nataro et al $^{4}$ for EAgg (figure). E. coli strain $\mathrm{K}_{12} \mathrm{~F}^{-} \mathrm{lac}^{+} \mathrm{Nal}^{+}$(a gift from Dr M. Katouli, Karolinska Institute, Stockholm, Sweden) was used as a non-adherent control and 

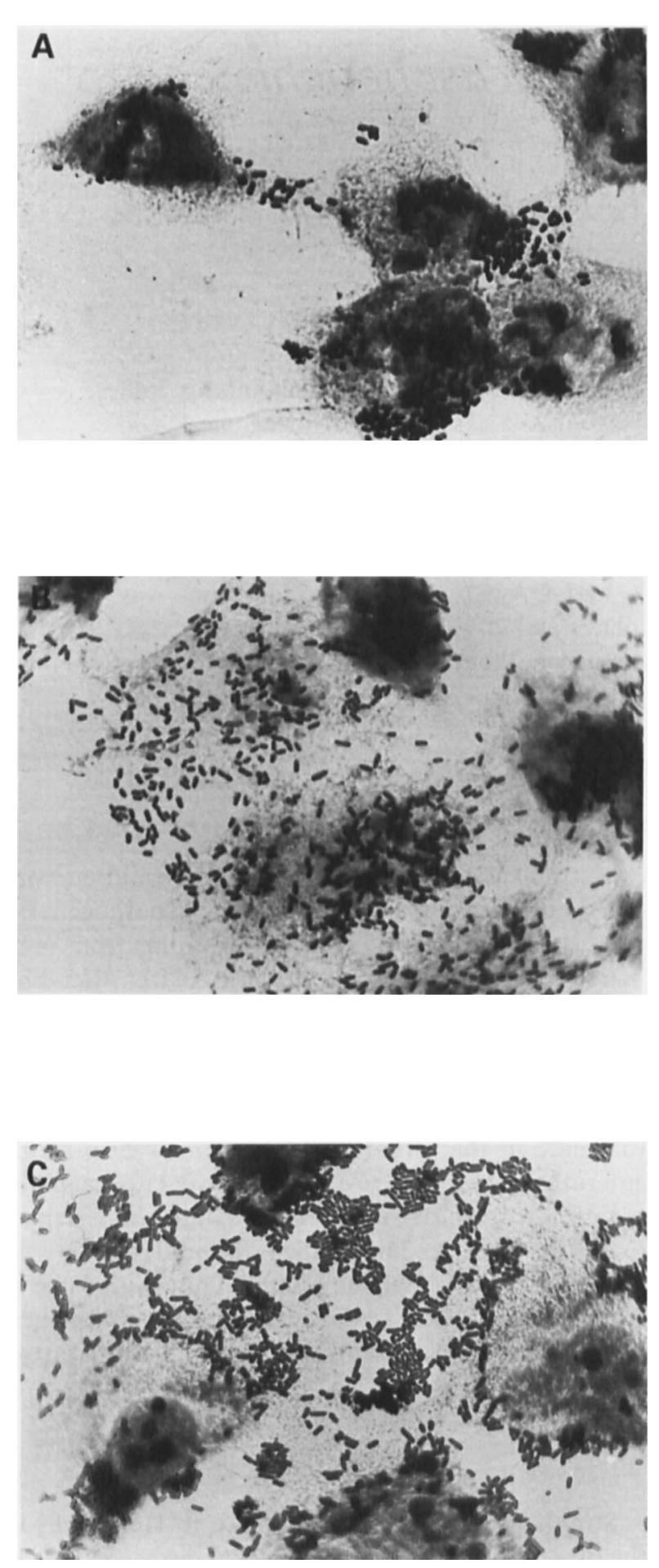

Figure. Cultured HeLa cells incubated with strains of $E$. coli showing (A) LA, (B) DA, (C) EAgg.

strains showing LA, DA, and EAgg patterns were kindly provided by Dr J. B. Kaper, Center for Vaccine Development, University of Maryland, MD, USA.

\section{Antibiotic sensitivity test}

Adherent strains were tested for their sensitivity to various commonly used antibiotics by the disk diffusion method. ${ }^{10}$ Antibiotics tested were: ampicillin $10 \mu \mathrm{g}$, nalidixic acid $30 \mu \mathrm{g}$, cephalothin $30 \mu \mathrm{g}$, strep- tomycin $10 \mu \mathrm{g}$, gentamicin $10 \mu \mathrm{g}$, tetracycline $30 \mu \mathrm{g}$, trimethoprim-sulphamethoxazole $1.25+23.75 \mu \mathrm{g}$, nitrofurantoin $30 \mu \mathrm{g}$, kanamycin $30 \mu \mathrm{g}$ and chloramphenicol $30 \mu \mathrm{g}$. All disks were obtained from bioMérieux, France.

\section{Statistical analysis}

To determine the statistical significance of the data, the chi-squared $\left(\chi^{2}\right)$ test was used.

\section{Results}

Of the $309 E$. coli strains isolated from cases of diarrhoea studied for their adherence pattern on HeLa cells, $14(4.5 \%)$ exhibited LA, $18(5.8 \%)$ DA, six (1.9\%) LA/DA, 99 (32.03\%) EAgg and four (1.2\%) $\mathrm{EAgg} / \mathrm{LA}$. In contrast, of the 100 isolates from control cases two (2\%) demonstrated LA, two (2\%) DA, two (2\%) LA/DA 17 (17\%) EAgg, six (6\%) EAgg/LA and one $(1 \%)$ DA/EAgg patterns.

Overall, $45.63 \%$ of the isolates from cases of diarrhoea were adherent whereas adherence to HeLa cells was observed in only $30 \%$ of the control isolates (table I). Association of EAgg strains with diarrhoea among these non-EPEC isolates was statistically significant $(32.03 \%$ in cases of diarrhoea and $17 \%$ in controls $\left.\mathrm{p}<0.005, \chi^{2}=8.409\right)$. On the other hand LA

Table I. Prevalence of adherent $E$. coli strains from cases of diarrhoea and controls

\begin{tabular}{lccc}
\hline $\begin{array}{l}\text { Adherence } \\
\text { pattern }\end{array}$ & $\begin{array}{c}\text { Strains from } \\
309 \text { cases } \\
\text { of diarrhoea }\end{array}$ & $\begin{array}{c}\text { Strains from } \\
100 \text { controls }\end{array}$ & p value \\
\hline LA & 14 & 2 & $<0 \cdot 3$ \\
DA & 18 & 2 & $<0 \cdot 2$ \\
EAgg & 99 & 17 & $<0 \cdot 005$ \\
LA/DA & 6 & 2 & NT \\
LA/EAgg & 4 & 6 & NT \\
DA/EAgg & 0 & 1 & - \\
Total & 141 & 30 & \\
\hline
\end{tabular}

$\mathrm{p}<0.05$ was considered significant

NT, not tested.

Table II. Distribution of antibiotic resistance determinants amongst $E$. coli isolates with different adherence patterns

\begin{tabular}{|c|c|c|c|c|c|c|c|}
\hline \multirow{2}{*}{$\begin{array}{l}\text { Adherence } \\
\text { pattern }\end{array}$} & \multicolumn{7}{|c|}{ Number of resistance markers } \\
\hline & Nil & 1 & 2 & 3 & 4 & 5 & Total \\
\hline EAgg & 5 & 3 & 0 & 4 & 14 & 73 & 99 \\
\hline $\mathrm{DA}^{\circ}$ & 0 & 0 & 0 & 1 & 3 & 15 & 18 \\
\hline LA & 1 & 0 & 0 & 0 & 0 & 13 & 14 \\
\hline $\mathrm{LA} / \mathrm{DA}$ & 0 & 0 & 0 & 1 & 0 & 5 & 6 \\
\hline LA/EAgg & 0 & 0 & 0 & 0 & 0 & 4 & 4 \\
\hline Total & 6 & 3 & 0 & 6 & 17 & 110 & 141 \\
\hline
\end{tabular}


and DA were not found to be specific markers of these non-EPEC strains as far as diarrhoea was concerned $\left(\mathrm{p}<0 \cdot 3, \chi^{2}=1 \cdot 287\right.$ and $\mathrm{p}<0 \cdot 2, \chi^{2}=2 \cdot 376$, respectively). Strains showing EAgg exhibited 39 different antibiotic resistance patterns and the majority carried more than two resistance markers. The isolates showed resistance to cephalothin, trimethoprim-sulphamethoxazole, tetracycline, ampicillin and streptomycin either singly or in combination (table II).

\section{Discussion}

The role of EAgg strains of E.coli in diarrhoea is still unclear. In this study, we have shown a close association with diarrhoea, similar to results reported from India and Chile. ${ }^{8,9}$ However, studies from Brazil and Thailand have failed to confirm such a conclusion. ${ }^{7,11}$ The LA pattern has been shown to be a specific marker for EPEC, whereas the role of strains with the DA pattern is still unclear. ${ }^{5-7}$ In the present study neither of these two patterns showed any significant association of non-EPEC strains with diarrhoea. Antibacterial sensitivity tests revealed that of the EAgg E. coli strains examined in this study, $>90 \%$ carried one or more resistance determinant. EAgg $E$. coli are not detected in any of the clinical laboratories in Iran due to the lack of availability of technical facilities for either tissue culture assays or use of specific DNA probes. Detection of this level of resistance to several antibiotics could indicate indiscriminate prescription of antibiotics to children in the absence of positive isolation of any recognised bacterial pathogen. In a recent publication ${ }^{12}$ different methods for detection of adherent $E$. coli were assessed and it was concluded that the modified UTH method in which the incubation period of bacteria with the $\mathrm{HeLa}$ cells was extended to either 3 or $4 \mathrm{~h}$ after the first washing step increased the rate of detection of EAgg. Our study was conducted with only the procedure of Scaletsky ${ }^{3}$ which could have resulted in underscoring the number of EAgg strains, especially in the case of four isolates exhibiting the LA/EA pattern and some of the strains showing DA pattern. However, the data obtained showed a statistically significant association between the EAgg pattern and diarrhoea amongst the E.coli isolates not belonging to any of the known classes of diarrhoeagenic $E$. coli, although more detailed epidemiological investigations in different parts of the country are required to fully determine the role of this class of $E$. coli.

In the present study, a correlation was observed between the EAgg pattern in vitro and surface clumping of bacteria in the broth culture. Adherence of EAgg E. coli to human or animal mucosal cells ${ }^{13}$ has also been found to be related to haemagglutinating ability (HA). This correlation was not observed in this study (unpublished data) nor in that reported from India ${ }^{14}$ which suggested independence of adherence from cell surface hydrophobicity and HA.

The presence of aggregative adherence fimbriae-1 (AAF-1) has been reported to be responsible for this pattern of adherence. ${ }^{15}$ Studies on the presence of a similar adherence factor in EAgg strains of $E$. coli and the existence of its possible analogue in EPEC isolates exhibiting the EAgg pattern is under investigation.

We are indebted to Mrs Z. S. Mirfattah, Mssrs M. Byramian, R. Jirsaraie and H. Soleimani for their technical help.

\section{References}

1. Ulshen MH, Rolo JL. Pathogenesis of Escherichia coli gastroenteritis in man-another mechanism. $N$ Engl $J$ Med $1980 ; 302$ : 99-101.

2. Cravioto A, Gross RJ, Scotland SM, Rowe B. An adhesive factor found in strains of Escherichia coli belonging to the traditional infantile enteropathogenic serotypes. Curr Microbiol 1979; 3: 95-99.

3. Scaletsky ICA, Silva MLM, Trabulsi LR. Distinctive patterns of adherence of enteropathogenic Escherichia coli to HeLa cells. Infect Immun 1984; 45: 534-536.

4. Nataro JP, Kaper JB, Robins-Browne R, Prado V, Vial P Levine MM. Patterns of adherence of diarrheagenic Escherichia coli to HEp-2 cells. Pediatr Infect Dis J 1987; 6: 829-831.

5. Cravioto A, Reyes RE, Ortega R, Fernández G, Hernández R, López D. Prospective study of diarrhoeal disease in a cohort of rural Mexican children: incidence and isolated pathogens during the first two years of life. Epidemiol Infect $1988 ; 101$ : 123-134.

6. Levine MM, Prado V, Robins-Browne RM et al. Use of DNA probes and HEp-2 cell adherence assay to detect diarrheagenic Escherichia coli. J Infect Dis 1988; 158: $224-228$.

7. Gomes TAT, Blake PA, Trabulsi LR. Prevalence of Escherichia coli strains with localized, diffuse, and aggregative adherence to HeLa cells in infants with diarrhea and matched controls. J Clin Microbiol 1989; 27: 266-269.

8. Bhan MK, Raj P, Levine MM et al. Enteroaggregative

Escherichia coli associated with persistent diarrhea in a cohort of rural children in India. J Infect Dis 1989; 159: 1061-1064.

9. Vial PA, Robins-Browne R, Lior $\mathrm{H}$ et al. Characterization of enteroadherent-aggregative Escherichia coli, a putative agent of diarrheal disease. $J$ Infect Dis $1988 ; 158$ : 70-79.

10. WHO Expert Committee on Biological Standardization. $\mathrm{WHO}$ Tech Rep Ser 1977; 610: 98-128.

11. Echeverria $\mathrm{P}$, Serichantalerg $\mathrm{O}$, Changchawalit $\mathrm{S}$ et al. Tissue culture-adherent Escherichia coli in infantile diarrhea. $J$ Infect Dis 1992; 165: 141-143.

12. Haider K, Faruque SM, Albert MJ, Nahar S, Neogi PKB, Hossain A. Comparison of a modified adherence assay with existing assay methods for identification of enteroaggregative Escherichia coli. J Clin Microbiol 1992; 30: $1614-1616$.

13. Yamamoto T, Endo S, Yokata T, Echeverria P. Characteristics of adherence of enteroaggregative Escherichia coli to human and animal mucosa. Infect Immun 1991; 59: 3722-3729.

14. Ghosh AR, Nair GB, Naik TN, Paul M, Pal SC, Sen D. Enteroadherent Escherichia coli is an important diarrhoeagenic agent in infants aged below 6 months in Calcutta, India. J Med Microbiol 1992; 36: 264-268.

15. Nataro JP, Deng Y, Maneval DR, German AL, Martin WC, Levine MM. Aggregative adherence fimbriae I of enteroaggregative Escherichia coli mediate adherence to HEp-2 cells and haemagglutination of human erythrocytes. Infect Immun 1992; 60: 2297-2304. 